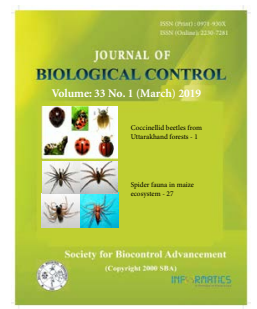

Research Article

\title{
Studies on natural enemies of Pink pineapple mealybug, Dysmicoccus brevipes (Cockerell) (Hemiptera: Pseudococciade) in Kerala
}

\author{
G. MANJUSHREE*, MANI CHELLAPPAN and MADHU SUBRAMANIAN \\ Department of Agricultural Entomology, College of Horticulture, Vellanikkara, Kerala Agricultural University, Thrissur - 680656, \\ Kerala, India \\ *Corresponding author E-mail:Manjushreenayak37@gmail.com
}

ABSTRACT: Purposive survey was conducted to document the natural enemies associated with Dysmicoccus brevipes in pineapple growing areas of Kerala. The survey was carried out between January to May 2016 at monthly intervals. Infested fruits were collected from pineapple fields and observed for natural enemies. The natural enemies recorded included four predators [Spalgis epeus (Westwood), Cacoxenus perspicax (Knab) and two species of Scymnus which are yet to be identified], one parasitoid (Chartocerus sp.) and the fungus Aspergillus sp.

KEY WORDS: Dysmicoccus brevipes, parasitoid, predator, Spalgis epeus

(Article chronicle: Received: 07-10-2018; Revised: 21-03-2019; Accepted: 25-03-2019)

\section{INTRODUCTION}

Pink pineapple mealybug, Dysmicoccus brevipesis is reported as serious pest of pineapple in (KAU, 2002). It is also found infesting various crops viz., the roots and basal stem region of pepper (Devasahayam et al., 2009), rhizome of white ginger flower, Hedychium coronarium Koenig (Hernandez and Martinez, 2012) on Arecanut (Areca catechu L.) (Basavaraju et al., 2013). Apart from direct damage, it also causes indirect damage by transmitting two types of viruses namely Pineapple Mealybug Wilt associated virus-1 [PMWaV-1] and Pineapple Mealybug Wilt associated virus-2 [PMWaV-2] (Sether et al., 2001). Infested plants show the symptoms of yellowing of leaves, stunting, wilting and rotting of roots followed by reduced yield and low plant population (Bua et al., 2013). Mealybugs are difficult to get controlled with chemicals since they are covered with wax coating. Management of mealybugs using of synthetic insecticides results in residual toxicity in fruits and may cause human health hazards. Therefore, adopting biological control measures is more appropriate. The objective of the present study is to identify the natural enemies associated with $D$. Brevipes in pineapple plantation.

\section{MATERIALS AND METHODS}

\section{Selection of areas for the collection of natural enemies}

Purposive survey was carried out in major pineapple growing districts of Kerala viz., Ernakulam, Idukki and Thrissur. Among these districts, different locations were selected for the survey, depending on the extent of pineapple cultivation (Table 1) and GPS co-ordinates of the selected location were recorded. The survey was carried out at monthly intervals from January to May, 2016. Two infested fruits as well as plants along with the mealybugs were collected from the farmer's fields and observed for the presence of natural enemies like predators, parasitoids and diseased insect.

Table 1. Locations selected for conducting survey

\begin{tabular}{|l|l|}
\hline \multicolumn{1}{|c|}{ Districts } & \multicolumn{1}{c|}{ Locations } \\
\hline Ernakulam & $\begin{array}{l}\text { Kaloor, Kalloorkkad, Vazhakulam, Nadukkara, } \\
\text { Peramangalam }\end{array}$ \\
\hline Idukki & Kumaramangalam, Thodupuzha \\
\hline Thrissur & Vellanikkara, Kootala, Poomala \\
\hline
\end{tabular}

\section{Collection of natural enemies}

Infested pineapple fruits and roots collected from the surveyed localities were examined for the presence of predators. The immature stages of predators were collected and reared to the adult stage. After the emergence of the adults, they were separated from polythene cover and preserved in alcohol $(70 \%)$ and got identified. The predators got identified at the Department of Agricultural Entomology, College of Horticulture, Kerala Agricultural University, 
Thrissur. Similar procedure was followed for the parasitoids also. After its emergence from parasitized mealybugs, the parasitoids collected were preserved in alcohol $(70 \%)$. The preserved specimens were got identified from Aligarh Muslim University, Uttar Pradesh, India.

\section{Identification of ant species associated with the Dysmicoccus brevipes}

Ants were found associated with the mealybugs in pineapple fields under natural conditions. The ants were collected from the field and preserved in alcohol $(70 \%)$. Specimens were got identified from St. Xavier's College, Aluva.

\section{Isolation of entomopathogenic fungus of Dysmicoccus brevipes}

Mealybug samples from infested fruits collected from pineapple fields were observed for the presence of dead mealybugs. The mycosed mealybug specimens were removed using a fine camel hairbrush and surface sterilized with sodium hypochlorite $(1 \%)$ solution for one minute and then washed three times with sterile distilled water. Then it was transferred aseptically to Petri dishes lined with moist filter paper and incubated at room temperature of $\left(29 \pm 1^{\circ} \mathrm{C}\right)$ for two days to observe for mycelial growth, if any. Once the fungal growth was visible externally, the specimens were carefully picked up with needle and kept in Petri dish of $8.5 \mathrm{~cm}$ diameter containing Potato Dextrose Agar medium (PDA). The Petri dishes were incubated at room temperature and examined daily for the growth of fungal mycelia.

\section{Pathogenicity test}

Pathogenicity test was carried out by spraying the spore suspension prepared from the isolated fungus on the healthy mealybug.

\section{RESULTS AND DISCUSSION} Survey and documentation of natural enemies of
Dysicoccus brevipes

Samples collected from different locations of Ernakulam, Idukki and Thrissur consisted of four species of predators, a parasitoid and a fungus. Predators included Cacoxenus perspicax (Knab) (Drosophilidae: Diptera), Spalgis epeus (Westwood) (Lycaenidae: Lepidoptera), two species of Scymnus (Coccinellidae: Coleoptera), parasitoid, Chartocerus sp. (Signiphoridae: Hymenoptera) and the fungus Apergillus sp. (Table 2).

Table 2. Presence of natural enemies in selected locations of Ernakulam, Idukki and Thrissur districts in Kerala

\begin{tabular}{|c|c|c|c|c|c|c|c|c|c|c|c|c|c|c|c|c|c|}
\hline \multirow[t]{3}{*}{ Districts } & \multirow[t]{3}{*}{ Location } & \multirow{3}{*}{$\begin{array}{l}\text { GPS } \\
\text { Co-ordinates }\end{array}$} & \multicolumn{15}{|c|}{ Natural enemies } \\
\hline & & & \multicolumn{3}{|c|}{ January 2016} & \multicolumn{3}{|c|}{ February 2016} & \multicolumn{3}{|c|}{ March 2016} & \multicolumn{3}{|c|}{ April 2016} & \multicolumn{3}{|c|}{ May 2016} \\
\hline & & & $\mathrm{Pr}$ & $\mathrm{Pa}$ & $\mathrm{F}$ & $\operatorname{Pr}$ & $\mathrm{Pa}$ & $\mathrm{F}$ & $\operatorname{Pr}$ & $\mathrm{Pa}$ & $\mathrm{F}$ & $\operatorname{Pr}$ & $\mathrm{Pa}$ & $\mathrm{F}$ & $\operatorname{Pr}$ & $\mathrm{Pa}$ & $\mathrm{F}$ \\
\hline \multirow[t]{5}{*}{ Ernakulam } & Kaloor & $\begin{array}{l}9^{\circ} 59^{\prime} 49.524^{\prime \prime} \mathrm{N} \\
76^{\circ} 18^{\prime} 10.134^{\prime \prime} \mathrm{E}\end{array}$ & Sc. & - & - & $\mathrm{Sc}$ & - & - & $\mathrm{Sc}$ & - & - & $\mathrm{Sc}$ & - & - & $\mathrm{Sc}$ & - & - \\
\hline & Kalloorkkad & $\begin{array}{l}9^{\circ} 58^{\prime} 11.744^{\prime \prime} \mathrm{N} \\
76^{\circ} 40^{\prime} 18.743^{\prime \prime} \mathrm{E}\end{array}$ & $\begin{array}{l}\text { Sc, } \\
\text { Sp }\end{array}$ & - & As & $\begin{array}{l}\text { Sc, } \\
\text { Sp }\end{array}$ & - & - & $\mathrm{Sc}$ & - & - & $\begin{array}{l}\text { Sc, } \\
\text { Sp }\end{array}$ & - & - & $\begin{array}{l}\mathrm{Sc}, \\
\mathrm{Sp}\end{array}$ & - & - \\
\hline & Peramangalam & $\begin{array}{l}10^{\circ} 34^{\prime} 24.848^{\prime \prime} \mathrm{N} \\
76^{\circ} 10^{\prime} 10.844^{\prime \prime} \mathrm{E}\end{array}$ & - & - & - & - & - & - & - & - & - & - & - & - & - & - & - \\
\hline & Nadukkara & $\begin{array}{l}9^{\circ} 56^{\prime} 26.056^{\prime \prime} \mathrm{N} \\
76^{\circ} 36^{\prime} 54.997^{\prime \prime} \mathrm{E}\end{array}$ & $\mathrm{Sc}$ & - & - & $\mathrm{Sc}$ & - & - & $\mathrm{Sc}$ & - & - & $\begin{array}{l}\text { Sc, } \\
\text { C }\end{array}$ & - & - & $\mathrm{Sc}$ & - & - \\
\hline & Vazhakulam & $\begin{array}{l}9^{\circ} 56^{\prime} 49.049^{\prime \prime} \mathrm{N} \\
76^{\circ} 36^{\prime} 9.241^{\prime \prime} \mathrm{E}\end{array}$ & - & - & - & - & - & - & $\mathrm{Sc}$ & - & - & $\mathrm{Sc}$ & - & - & $\mathrm{Sc}$ & $\mathrm{Ch}$ & - \\
\hline \multirow[t]{2}{*}{ Idukki } & $\begin{array}{l}\text { Kumaraman- } \\
\text { galam }\end{array}$ & $\begin{array}{l}9^{\circ} 56^{\prime} 30.887^{\prime \prime} \mathrm{N} \\
76^{\circ} 42^{\prime} 58.810^{\prime \prime} \mathrm{E}\end{array}$ & - & - & - & - & - & - & - & - & - & - & - & - & - & - & - \\
\hline & Thodupuzha & $\begin{array}{l}9^{\circ} 53^{\prime} 34.728^{\prime \prime} \mathrm{N} \\
76^{\circ} 43^{\prime} 19.589^{\prime \prime} \mathrm{E}\end{array}$ & $\mathrm{Sc}$ & - & - & $\mathrm{Sc}$ & - & - & $\mathrm{Sc}$ & - & - & $\begin{array}{l}\text { Sc, } \\
\text { Sp }\end{array}$ & - & - & $\begin{array}{l}\mathrm{Sc}, \\
\mathrm{C}\end{array}$ & - & - \\
\hline \multirow[t]{3}{*}{ Thrissur } & Kootala & $\begin{array}{l}18^{\circ} 27^{\prime} 38.290^{\prime \prime} \mathrm{N} \\
73^{\circ} 54^{\prime} 50.119^{\prime \prime} \mathrm{E}\end{array}$ & - & - & - & - & - & - & - & - & - & - & - & - & - & - & - \\
\hline & Poomala & $\begin{array}{l}10^{\circ} 36^{\prime} 34.438^{\prime \prime} \mathrm{N} \\
76^{\circ} 14^{\prime} 2.558^{\prime \prime} \mathrm{E}\end{array}$ & - & - & - & - & - & - & - & - & - & - & - & - & - & - & - \\
\hline & $\begin{array}{l}\text { Vellanikkara } \\
\text { (PRS) }\end{array}$ & $\begin{array}{l}10^{\circ} 32^{\prime} 42.770^{\prime \prime} \mathrm{N} \\
76^{\circ} 16^{\prime} 26.324^{\prime \prime} \mathrm{E}\end{array}$ & $\begin{array}{l}\text { Sc, } \\
\text { Sp, } \\
\text { C }\end{array}$ & $\mathrm{Ch}$ & As & $\begin{array}{l}\text { Sc, } \\
\text { Sp, } \\
\text { C }\end{array}$ & - & As & $\begin{array}{l}\text { Sc, } \\
\text { C, }\end{array}$ & & - & - & - & - & - & - & - \\
\hline
\end{tabular}

Pr-Predator, Pa-parasitoids, F-Fungus, Sc-Scymnus sp., Sp-Spalgis epeus, C-Cacoxenus perspicax, Ch-Chartocerus sp., A-Aspergillus sp. GPS- Global Positioning System 


\section{Relative abundance of the natural enemies in different locations}

Among different natural enemies collected from selected locations of Ernakulam, Iduki and Thrisur districts, Scymnus sp. was found to be the most abundant in all the six locations and it accounted for 68.75 per cent of the total natural enemies reported from all the locations (Table 3). It was followed by Spalgis epeus, which was reported in larger numbers only from three locations viz., Kalloorkkad, Thodupuzha and Vellanikkara with the occurrence of 37.5, 28.12 and 18.42 per cent, respectively. Similarly, Cacoxenus perspicax was also collected from three locations which includes Nadukkara (10\%), Thodupuzha (9.37\%) and Vellanikkara (21.05\%). During the survey while, few numbers of parasitoid, Chartocerus sp. was observed and was reported from only in Vazhakulam and Vellanikkara.

Aspergillus sp. infection was noticed on D. brevipes in Kalloorkkad and Vellanikkara. It appeared to be a chance infection. However, under laboratory condition the isolated Aspergillus sp. failed to cause infection when sprayed the same on the mealybugs.

\section{Ants associated with Dysmicoccus brevipes}

Two species of ants, Camponotus mitis (Smith) (Formicidae: Formicinae) and Technomyrmex albipes (Smith) (Formicidae: Dolichoderinae) were found associated with $D$. brevipes in the pineapple fields (Plate 13). These ants were collected from the mealybug infested pineapple plants of Nadukkara (Ernakulam district) and found tending the mealy bugs below the ground.
Survey and documentation of natural enemies of Dysmicoccus brevipes

Among the total number of natural enemies collected from different locations of Ernakulam, Idukki and Thrissur district during January to May 2016, Scymnus sp. was the most abundant predator with 68.75 per cent relative abundancein all the locations (Table 3). Avre et al. (2011) observed that the increase in the population of Scymnus coccivora was proportional to the incidence of Phenococcus solenopsis infesting on hibiscus plant commencing first fortnight of October ( 0.36 per 25 plants) and attaining the maximum during second fortnight of November (1.12/25 plants).

Incidence of Spalgis epeus was first recorded in $D$. brevipes and it accounted for about 17.61 per cent of the total insect natural enemies collected from all the locations. Thangamalar et al. (2010) observed large number of $S$. epeus in the mulberry ecosystem infested by Paracoccus marginatus especially between June to October when other natural enemies were absent, while declined during October and November, when the presence of other natural enemies like Cryptolaemus montrouzeiri Mulsant and Scymnus sp. were abundant. This finding supports the reason for low population of $S$. epeus admist high population of Scymnus sp. Cham et al. (2013) also reported high number of $S$. epeus in the papaya plantation infested with $P$. marginatus accounting for an average of 35 larvae between September 2010 to March 2011, whereas 80 per cent of $S$. epeus was collected during January and February. The minimum occurrence of $S$. epeus during the earlier months was due to the low incidence of mealybugs, D. brevipes.

Table 3. Relative abundance of predators and parasitoid of Dysmicoccus brevipes in selected locations of Ernakulam, Idukki and Thrissur districts

\begin{tabular}{|c|c|c|c|c|c|c|c|c|c|}
\hline \multirow{2}{*}{ Location } & \multirow{2}{*}{$\begin{array}{l}\text { Number } \\
\text { of natural } \\
\text { enemies }\end{array}$} & \multicolumn{3}{|c|}{ Number of predators } & \multirow{2}{*}{$\begin{array}{c}\begin{array}{c}\text { Number of } \\
\text { parasitoid }\end{array} \\
\begin{array}{c}\text { Chartocerus } \\
\text { sp. }\end{array}\end{array}$} & \multicolumn{2}{|c|}{$\begin{array}{c}\text { Relative abundance of } \\
\text { predators }\end{array}$} & \multicolumn{2}{|c|}{$\begin{array}{l}\text { Relative abundance of } \\
\text { parasitoid }\end{array}$} \\
\hline & & $\begin{array}{l}\text { Scymnus } \\
\text { sp. }\end{array}$ & $\begin{array}{l}\text { Spalgius } \\
\text { epeus }\end{array}$ & $\begin{array}{l}\text { Cacoxenus } \\
\text { perspicax }\end{array}$ & & $\begin{array}{l}\text { Scymnus } \\
\text { sp. }\end{array}$ & $\begin{array}{l}\text { Spalgius } \\
\text { epeus }\end{array}$ & $\begin{array}{l}\text { Cacoxenus } \\
\text { perspicax }\end{array}$ & $\begin{array}{c}\text { Chartocerus } \\
\text { sp. }\end{array}$ \\
\hline Kaloor & 26 & 26 & - & - & - & 100 & - & - & - \\
\hline Kalloorkkad & 40 & 25 & 15 & - & - & 62.5 & 37.5 & - & - \\
\hline Nadukkara & 20 & 18 & - & 2 & - & 90 & - & 10 & - \\
\hline Vazhakulam & 20 & 14 & - & - & 6 & 70 & - & - & 30 \\
\hline Thodupuzha & 32 & 20 & 9 & 3 & - & 62.5 & 28.12 & 9.37 & - \\
\hline Vellanikkara & 38 & 18 & 7 & 8 & 5 & 47.36 & 18.42 & 21.05 & 13.15 \\
\hline Total & 176 & 121 & 31 & 13 & 11 & 68.75 & 17.61 & 7.39 & 6.25 \\
\hline
\end{tabular}


The drosophilid predator, Cacoxenus perpsicax, accounted for 7.39 per cent of the total insect natural enemies collected from few places viz., Nadukkara, Thodupuzha and Vellanikkara. Goolsby et al. (2002) also collected C. perspicax on the Maconellicoccus hirsutus from different location in Australia and found to be density dependent. Similarly, Sundararaj (2008) collected few numbers of $C$. perspicax from spherical mealybug, Nipaecoccus viridis infesting sandalwood.

Chartocerus sp., was also recorded (6.25\%) from Vazhakulam and Vellanikkara. Beltra et al. (2012) recorded sporadic occurrence of about 0.9 per cent of Chartocerus sp. of the total number of parasitoid collected.

During the survey, two ant species viz., Camponotus mitis and Technomyrmex albipes were found symbiotically associated with $D$. brevipes. Similar association by $C$. compressus in arecanut plant infested with $D$. brevipes (Basavaraju et al., 2013) and Paracoccus marginatus with C. compressus and T. albipes (Gowda et al., 2013) were reported.

\section{REFERENCES}

Arve SS, Patel KG, Chavan SM, Vidhate PK. 2011. Investigation on population dynamics of hibiscus mealybug, Phenacoccus solenopsis Tinsley in relation to biotic factors under South Gujarat condition. J Biopestic. 4(2): 211-213.

Basavaraju SL, Revanappa SB, Prashant K, Rajkumar, Anand Kanatti, Sowmya HC. 2013. Bio-ecology and management of arecanut scale, Parasaissetia nigra (Neitner) and mealybug, Dysmicoccus brevipes (Cockerell). Indian J Agric Res. 47(5): 436-440.

Beltra A, Tena A, Soto A. 2012. Fortuitous biological control of the invasive mealybug, Phenacoccus peruvianus in Southern Europe. Biocontrol. Available from: http://www.researchgate. net. 27 June 201 DOI 10.1007/s10526-10526-012-9488-5

Bua B, Karungi J, Awube G. 2013. Occurrence and effects of pineapple mealybug wilt disease in central Uganda. J Agric Sci Technol. 3: 410-416.
Cham D, Davis H, Obeng-Ofori D, Owusu E. 2013. Field and laboratory studies on natural enemies associated with the newly invasive mealybug species, Paracoccus marginatus, and other pests of papaya in the eastern and greater Accra regions of Ghana. West Afric J Appl Ecol. 21(2): 23-35.

Devasayaham S, Kova KMA, Anandara M, Thomas T, Preethi. 2009. Distribution and ecology of root mealybugs associated with black pepper (Piper nigrum Linnaeus) in Karnataka and Kerala, India. Entomon 34: 147-154

Goolsby JA, Kirk AA, Meyerdirk DE. 2002. Seasonal phenology and natural enemies of Maconellicoccus hirsutus (Hemiptera: Pseudococcidae) in Australia. Fla Entomologist 85(3): 494-498. https://doi.org/10.1653/00154040(2002)085[0494:SPANEO]2.0.CO;2

Hernandez IM, Martinez MA. 2012. Dysmicoccus brevipes (Cockerell) (Hemiptera: Pseudococcidae) new report on Hedychium coronorium Koenig, flower butterfly in Cuba. Rev Prot Veg. 27: 54-55.

KAU (Kerala Agricultural University). Package of Practices Recommendations: Crops (12th Ed.). Kerala Agricultural University, Thrissur. 2002; 183p.

Sether DM,Hu JS.2001. The impact of pineapple mealybug wilt-associated virus-1 and reduced irrigation on pineapple yield. Aust Plant Pathol. 30: 31-36. https://doi.org/10.1071/ AP00060

Sundararaj R. 2008. Population dynamics, parasitoids and chemical control of the spherical mealybug, Nipaecoccus viridis on sandal. Indian J Plant Prot. 36(1): 15-18.

Thangamalar A, Subramanian S, Mahalingam CA. 2010. Bionomics of papaya mealybug, Paracoccus marginatus and its predator Spalgis epius in mulberry ecosystem. Karnataka J Agric Sci. 23(1): 39-41. 